\title{
Protective Effect of Melatonin against Oxidative Stress-Induced Apoptosis and Enhanced Autophagy in Human Retinal Pigment Epithelium Cells
}

\author{
Chih-Chao Chang, ${ }^{1}$ Tien-Yi Huang, ${ }^{1}$ Hsin-Yuan Chen, ${ }^{1}$ Tsui-Chin Huang, ${ }^{2}$ Li-Chun Lin, ${ }^{2}$ \\ Yen-Jui Chang, ${ }^{3,4,5}$ and Shih-Min Hsia $\mathbb{\circledR}^{1,6,7,8}$ \\ ${ }^{1}$ School of Nutrition and Health Sciences, Taipei Medical University, Taipei, Taiwan \\ ${ }^{2}$ PhD Program for Cancer Biology and Drug Discovery, College of Medical Science and Technology, Taipei Medical University and \\ Academia Sinica, Taipei, Taiwan \\ ${ }^{3}$ Department of Ophthalmology, Yangming Branch, Taipei City Hospital, Taipei, Taiwan \\ ${ }^{4}$ Department of Optometry, University of Kang Ning, Taipei, Taiwan \\ ${ }^{5}$ Department of Health and Welfare, College of City Management, University of Taipei, Taipei, Taiwan \\ ${ }^{6}$ Graduate Institute of Metabolism and Obesity Sciences, Taipei Medical University, Taipei, Taiwan \\ ${ }^{7}$ School of Food and Safety, Taipei Medical University, Taipei, Taiwan \\ ${ }^{8}$ Nutrition Research Center, Taipei Medical University Hospital, Taipei, Taiwan
}

Correspondence should be addressed to Shih-Min Hsia; bryanhsia@tmu.edu.tw

Received 14 March 2018; Revised 1 June 2018; Accepted 6 June 2018; Published 5 August 2018

Academic Editor: Mohamed M. Abdel-Daim

Copyright (c) 2018 Chih-Chao Chang et al. This is an open access article distributed under the Creative Commons Attribution License, which permits unrestricted use, distribution, and reproduction in any medium, provided the original work is properly cited.

\begin{abstract}
Age-related macular degeneration (AMD) affects the retinal macula and results in loss of vision, and AMD is the primary cause of blindness and severe visual impairment among elderly people worldwide. AMD is characterized by the accumulation of drusen in the Bruch's membrane and dysfunction of retinal pigment epithelial (RPE) cells and photoreceptors. The pathogenesis of AMD remains unclear, and no effective treatment exists. Accumulating evidence indicates that oxidative stress plays a critical role in RPE cell degeneration and AMD. Melatonin is an antioxidant that scavenges free radicals, and it has anti-inflammatory, antitumor, and antiangiogenic effects. This study investigated the antioxidative, antiapoptotic, and autophagic effects of melatonin on oxidative damage to RPE cells. We used hydrogen peroxide $\left(\mathrm{H}_{2} \mathrm{O}_{2}\right)$ to stimulate reactive oxygen species production to cause cell apoptosis in ARPE-19 cell lines. Our findings revealed that treatment with melatonin significantly inhibited $\mathrm{H}_{2} \mathrm{O}_{2}$-induced RPE cell damage, decreased the apoptotic rate, increased the mitochondrial membrane potential, and increased the autophagy effect. Furthermore, melatonin reduced the Bax/Bcl-2 ratio and the expression levels of the apoptosisassociated proteins cytochrome $\mathrm{c}$ and caspase 7. Additionally, melatonin upregulated the expression of the autophagy-related proteins LC3-II and Beclin-1 and downregulated the expression of p62. Thus, melatonin's effects on autophagy and apoptosis can protect against $\mathrm{H}_{2} \mathrm{O}_{2}$-induced oxidative damage in human RPE cells. Melatonin may have multiple protective effects on human RPE cells against $\mathrm{H}_{2} \mathrm{O}_{2}$-induced oxidative damage.
\end{abstract}

\section{Introduction}

Age-related macular degeneration (AMD) is the leading cause of vision loss among elderly people in developed countries [1].
Approximately 50 million people experience AMD symptoms, and 14 million people are visually impaired because of AMD [2]; the prevalence of AMD is also increasing [3]. Abnormalities in retinal pigment epithelial (RPE) cells cause 
vision loss in patients with AMD, and impairment of normal physiological function in RPE cells is an early pathogenesis of AMD [4].

A growing body of evidence indicates that oxidative stress plays a critical role in RPE degeneration in AMD [5]. RPE cells are particularly vulnerable to oxidative stress caused by reactive oxygen species (ROS) [6] such as superoxide anion radicals, hydroxyl radicals, singlet oxygen, and hydrogen peroxide $\left(\mathrm{H}_{2} \mathrm{O}_{2}\right)[7,8]$. Research has revealed that several antioxidants and zinc-containing supplements can inhibit AMD progression and preserve vision [7, 9]. Therefore, protecting RPE cells by limiting oxidative stress may represent an effective approach to slowing or possibly reversing vision loss in patients with AMD.

In cellular systems, ROS are detrimental to cell survival; however, they are essential for cell signaling and regulation of cell proliferation, migration, differentiation, and gene expression $[10,11]$. Inhibiting ROS-induced RPE cell damage may inhibit AMD progression $[12,13]$. Catalase, superoxide dismutase (SOD), and glutathione peroxidase (GPx) are major enzymes that protect RPE cells through increased expression by effectively scavenging ROS and attenuating oxidative damage $[14,15]$. Malondialdehyde (MDA) is a product of lipid peroxidation, and its expression is generally used as a marker of lipid peroxidation and oxidative damage [16].

Apoptosis is a form of programmed cell death, and pathological apoptosis is associated with AMD [17, 18]. A previous study reported that the antiapoptotic Bcl-2 family proteins and apoptotic Bax proteins play important roles in mitochondrion-dependent extrinsic and intrinsic cell death pathways $[19,20]$. Bax could release cytochrome $c$ from the mitochondria into the cytosol to active caspase result in apoptosis [19, 20]. Moreover, caspase 7, Bax, Bcl-2, and cytochrome $\mathrm{c}$ are apoptotic markers in apoptosis.

Autophagy removes damaged organelles and protein aggregates of RPE cells, which is a crucial function because these cells are exposed to oxidative stress [21]. Studies have reported that autophagy occurs in RPE cells [22, 23]. However, failure or impairment of autophagy in RPE cells may cause an accumulation of aggregation-prone proteins, cellular degeneration, and finally the induction of cell death, all of which have been related to the pathogenesis of AMD $[21,23,24]$. In addition, research revealed that the preservation of autophagic activity is vital for preventing detrimental intracellular accumulation of damaged molecules [23]. Nevertheless, whether the autophagic pathway has a protective effect on RPE cells remains unclear; moreover, the relationship between oxidative stress and autophagy and how their interaction influences RPE cells require further clarification.

Melatonin (N-acetyl-5-methoxytryptamine) is a tryptophan-derived neurohormone that performs critical functions in the regulation of many physiological systems and processes including the circadian rhythm, immune system, cardiovascular system, and aging process $[25,26]$. A previous study mentions that the person to receive $250 \mathrm{mg}$ melatonin every $6 \mathrm{~h}$ for 25-30 days shows no toxic effects [27]. A study reported that the level of urinary melatonin was relatively low in patients with AMD [28]. Therefore, studying the relationship between the effects of melatonin and AMD may be constructive. Melatonin is mainly synthesized and secreted by the pineal gland [25]; however, studies have demonstrated other points of origin, including the gut, lens, and retina $[29,30]$. Melatonin is a strong antioxidant that scavenges ROS, decreases MDA, and stimulates the synthesis of antioxidant enzymes [31]. Furthermore, melatonin can protect cultured retinal pigment cells (ARPE-19) from oxidative damage and cell death induced by ischemia and $\mathrm{H}_{2} \mathrm{O}_{2}[32,33]$. The protective effect of melatonin on cells against oxidative stress may result from its scavenging of free radicals and the stimulation of the activity of antioxidant defense mechanisms $[34,35]$. It is also possible to activate the melatonin membrane receptors MT1 and MT2, which can stimulate the production of a variety of antioxidative enzymes through several signaling pathways [34, 36]. However, the molecular mechanism underlying the effect of melatonin on $\mathrm{H}_{2} \mathrm{O}_{2}$-induced oxidative damage and whether melatonin could induce the autophagic pathway to confer protective effects on RPE cells against damage remain unclear. The aim of this study was to investigate whether melatonin could protect ARPE-19 cells from $\mathrm{H}_{2} \mathrm{O}_{2}$-induced oxidative damage through antioxidative, antiapoptotic, and autophagic mechanisms and to investigate the molecular mechanism underlying the effects of melatonin on ARPE-19 cells.

\section{Materials and Methods}

2.1. Reagents and Antibodies. In this study, 3-(4,5-dimethylthiazol-2-yl)-2,5-diphenyltetrazolium bromide (MTT), melatonin, luzindole, paraformaldehyde, bovine serum albumin (BSA), $\mathrm{H}_{2} \mathrm{O}_{2}$, and sodium bicarbonate were obtained from Sigma-Aldrich (Sigma-Aldrich, St. Louis, MO, USA). The cell culture reagents were purchased from Gibco (Grand Island, NY, USA). Primary antibodies against apoptosis-related proteins (Bax, Bcl-2, Cyt c, cleavage-caspase 7, and caspase 7) and autophagy-related proteins (LC3, Beclin-1, mTOR, p-mTOR, ULK1, and p-ULK1) were obtained from Cell Signaling Technology (Danvers, MA, USA). Anti-p62 was obtained from Abcam (Cambridge, UK). Anti-GAPDH, $\beta$-actin, and rabbit/mouse IgG-horseradish peroxidase antibodies were purchased from Santa Cruz Biotechnology (Santa Cruz, CA).

2.2. Cell Culture. The ARPE-19 human RPE cell line was purchased from the American Type Culture Collection (USA). The cells were cultured in Dulbecco's modified Eagle's medium/Ham's F-12 (Corning, Tewksbury, USA) supplemented with $10 \%$ fetal bovine serum, $100 \mu \mathrm{g} / \mathrm{mL}$ streptomycin, and $100 \mathrm{U} / \mathrm{mL}$ penicillin at $37^{\circ} \mathrm{C}$ in an atmosphere containing $5 \% \mathrm{CO}_{2}$. The cells were passaged every 3 days once they grew to approximately $90 \%$ confluence.

2.3. Cell Viability Assay. Cell survival was tested using the MTT assay. ARPE-19 cells were seeded in 96-well plates at a density of $5 \times 10^{3}$ cells/well for a $24 \mathrm{~h}$ incubation process. The cells were treated with vehicle (ethanol) or melatonin at indicated concentrations for $48 \mathrm{~h}$, and they were then treated with $300 \mu \mathrm{M} \mathrm{H}_{2} \mathrm{O}_{2}$ for $24 \mathrm{~h}[34,37]$ (Figure S1). For 
the luzindole (melatonin receptor antagonist) test, the RPE cells were seeded as previously detailed. Luzindole was added to the culture medium at a final concentration of $50 \mu \mathrm{M}$ [34]. One hour later, melatonin was added to the culture medium followed by culturing for $48 \mathrm{~h}$, and $\mathrm{H}_{2} \mathrm{O}_{2}$ was then added followed by culturing for $24 \mathrm{~h}$. Cell viability was evaluated using the MTT assay. Briefly, the culture medium was then removed, and $100 \mu \mathrm{L}$ of phosphate-buffered saline (PBS) containing $0.5 \mathrm{mg} / \mathrm{mL}$ MTT was added, followed by incubation at $37^{\circ} \mathrm{C}$ for $3 \mathrm{~h}$ in the dark. Next, the crystals were dissolved with $100 \mu \mathrm{L}$ of dimethyl sulfoxide. The absorbance of each well was measured using an Epoch Microplate Spectrophotometer (BioTek, VT, USA) at a test wavelength of $570 \mathrm{~nm}$ with a reference wavelength of $630 \mathrm{~nm}$. The relative cell viability is presented as a percentage of cells treated with melatonin compared with those treated with the vehicle.

2.4. Lactate Dehydrogenase Release Assay. Cytotoxicity was measured through the lactate dehydrogenase (LDH) [38] release assay conducted using a commercial LDH assay kit (Cayman Chemical, Michigan, USA). In this assay, LDH reduces nicotinamide adenine dinucleotide (NAD) to $\mathrm{NADH}$, which then interacts with a specific probe to produce a color (optical density $\max =450 \mathrm{~nm}$ ).

2.5. Thiobarbituric Acid-Reactive Substance Assay. To measure intracellular MDA levels, the ARPE-19 cells were cultured in a $10 \mathrm{~cm}$ dish $\left(5 \times 10^{5}\right.$ cells $)$ for a $24 \mathrm{~h}$ incubation process. The cells were then added to different concentrations of melatonin for $48 \mathrm{~h}$, after which they were exposed to $\mathrm{H}_{2} \mathrm{O}_{2}(300 \mu \mathrm{M})$ for $24 \mathrm{~h}$. Thiobarbituric acid-reactive substances (TBARS) were quantified through comparing the absorption result with the standard curve of MDA equivalents generated through acid-catalyzed hydrolysis of 1,1,3,3-tetramethoxypropane.

2.6. Apoptosis Assay. Cell apoptosis was measured using an FITC Annexin V Apoptosis Detection Kit (BD Biosciences, Franklin Lakes, USA). Briefly, after treatment, the cells were washed with PBS and incubated in $400 \mu \mathrm{L}$ of binding buffer containing $2 \mu \mathrm{L}$ of annexin V-FITC and $2 \mu \mathrm{L}$ of propidium iodide in the dark for $15 \mathrm{~min}$ at room temperature. The stained samples were then analyzed on a FACSCalibur flow cytometry, and the results were analyzed using CellQuest.

2.7. ROS Assay. ROS production was determined using a $2^{\prime}, 7^{\prime}$-dichlorodihydrofluorescin diacetate $\left(\mathrm{DCFH}_{2}-\mathrm{DA}\right)$ staining assay (Abcam, Cambridge, UK). After melatonin treatment for $48 \mathrm{~h}$, the ARPE-19 cells were incubated with $20 \mu \mathrm{M} \mathrm{DCFH}{ }_{2}-\mathrm{DA}$ at $37^{\circ} \mathrm{C}$ for $30 \mathrm{~min}$ and then added to $300 \mu \mathrm{M} \mathrm{H}_{2} \mathrm{O}_{2}$ for $4 \mathrm{~h}$. The ARPE-19 cells were then resuspended in PBS and analyzed through flow cytometry. The percentage of fluorescence-positive cells was recorded on a FACSCalibur flow cytometer using excitation and emission filters of 485 and $530 \mathrm{~nm}$, respectively.

2.8. Western Blot Analysis. To determine their protein concentration, the ARPE-19 cells were lysed in immunoprecipitation assay buffer containing a phosphatase inhibitor cocktail tablet and a protease inhibitor mixture (Roche
Diagnostics, Basel, Switzerland). The protein concentration was assayed using a bicinchoninic acid assay kit (T-Pro Biotechnology, New Taipei County, Taiwan). Quantified protein lysates $(30 \mu \mathrm{g})$ were analyzed through sodium dodecyl sulfate-polyacrylamide gel electrophoresis, resolved on $7 \%-15 \%$ polyacrylamide gels. The proteins were then transferred into polyvinylidene difluoride membranes. Each membrane was blocked in 5\% BSA for $1.5 \mathrm{~h}$ and individually incubated with different primary antibodies against caspase 7, cleavage-caspase 7, Bax, Bcl-2, Cyt c, mTOR, p-mTOR (Ser2448), p-ULK1 (Ser757), ULK1, p62, LC3, Beclin-1, $\mathrm{GAPDH}$, and $\beta$-actin at $4^{\circ} \mathrm{C}$ overnight. After being washed three times with Tris-buffered saline mixed with $0.05 \%$ Tween-20 (TBST), the membrane was incubated with secondary antimouse or antirabbit antibodies ( $1: 10,000$; Cell Signaling Technology, MA, USA) for $1 \mathrm{~h}$ at room temperature. The signals were detected using a luminescent image analyzer: the Amersham Imager 600 (GE Healthcare Life Sciences, MA, USA). Signal intensities were then quantified using ImageJ.

2.9. Immunocytochemistry. ARPE-19 cells were washed three times with PBS and fixed with 4\% paraformaldehyde for $30 \mathrm{~min}$ at room temperature. The ARPE-19 cells were then washed with PBS and permeabilized with PBS containing $0.025 \%$ Triton X-100 for $15 \mathrm{~min}$. The cells were blocked with blocking solution (5\% $(w / v)$ BSA in 1X TBST). After blocking, the antibodies-including anti-LC3 and p62 at a 1:250 dilution-were applied, and the cells were incubated at $4{ }^{\circ} \mathrm{C}$ overnight. Alexa Fluor 594-conjugated rabbit antimouse secondary antibody was prepared in blocking buffer, followed by incubation with the ARPE-19 cells at room temperature for $1 \mathrm{~h}$. After washing, the cells were mounted with $4^{\prime}, 6$-diamidino-2-phenylindole-containing mounting medium and analyzed using a fluorescence microscope.

MitoView 633 is a far-red fluorescent dye that stains the mitochondria. The dye is membrane permeable and becomes brightly fluorescent on accumulation in the mitochondrial membrane. After treatment, the medium was removed and added to a prewarmed medium containing diluted MitoView 633. The cells were pelleted and resuspended in medium containing diluted MitoView 633. We conducted the tests at a staining concentration of $200 \mathrm{nM}$. The cells were visualized using a Zeiss LSM700 confocal microscope.

2.10. Statistical Analysis. Each experiment was repeated at least three times, the mean value of the repetitions was calculated, and this value was used in the statistical analysis. The data are presented as the means \pm standard deviations (SD). Statistical analyses were performed using one-way analysis of variance (ANOVA) analysis, followed by Tukey's post hoc test which was used to determine the differences between two groups or in multiple groups (GraphPad Prism 6.0; Systat Software, CA, USA). Statistical significance was selected to be $p<0.05$.

\section{Results}

3.1. Melatonin Protects ARPE-19 Cells from $\mathrm{H}_{2} \mathrm{O}_{2}$-Induced Oxidative Damage. To examine the cytotoxic effect of 


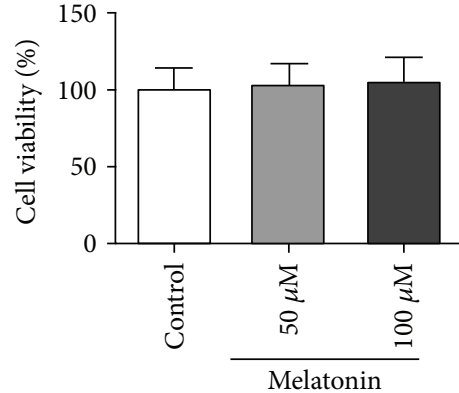

(a)

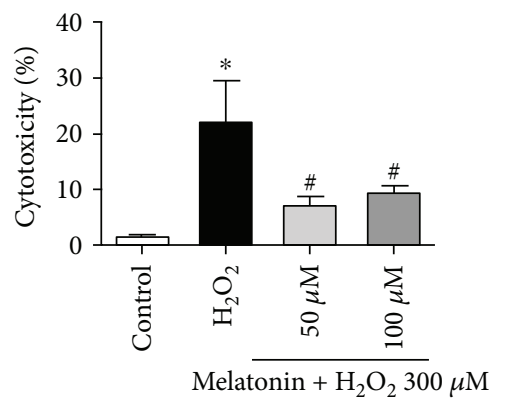

(d)

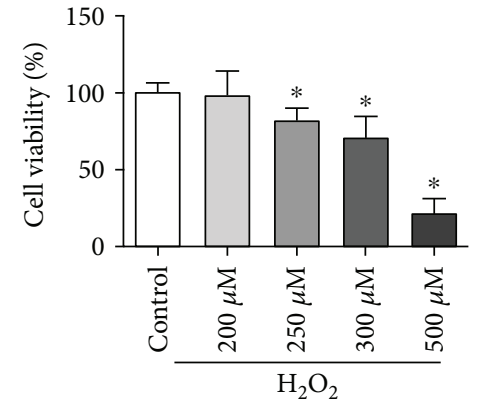

(b)

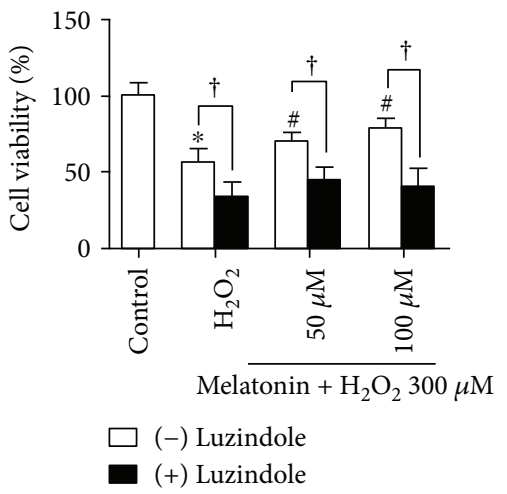

(e)

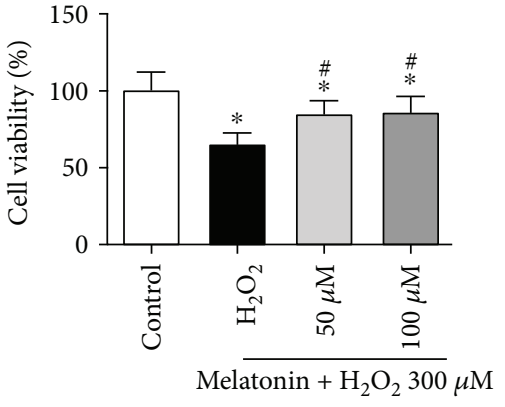

(c)

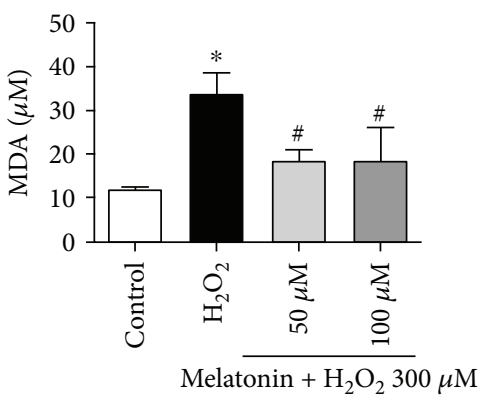

(f)

Figure 1: Melatonin protects RPE cells from $\mathrm{H}_{2} \mathrm{O}_{2}$ damage. ARPE-19 cells were treated with different concentrations of melatonin, luzindole (melatonin receptor antagonist), and/or $\mathrm{H}_{2} \mathrm{O}_{2}$. MTT assay was preformed to measure the viability of ARPE-19 cells after melatonin exposed for $48 \mathrm{~h}$ (a). MTT assay was preformed to measure the viability of ARPE- 19 cells after $\mathrm{H}_{2} \mathrm{O}_{2}$ exposed for $24 \mathrm{~h}$ (b). MTT assay was preformed to measure the viability of ARPE-19 cells which pretreatment melatonin for $48 \mathrm{~h}$ and then $\mathrm{H}_{2} \mathrm{O}_{2}$ exposed for $24 \mathrm{~h}$ (c). Cell cytotoxicity was determined using the LDH release assay (d). MTT assay was preformed to measure the viability of ARPE-19 cells after luzindole exposed for $1 \mathrm{~h}(\mathrm{e})$. Lipid peroxidation was measured using the TBARS assay (f). Values are the mean $\pm \mathrm{SD}$. ${ }^{*} p<0.05$ versus the control group, ${ }^{\dagger} p<0.05$ comparison between cells treated with and without luzindole, and ${ }^{\#} p<0.05$ versus $\mathrm{H}_{2} \mathrm{O}_{2}$-treated cells.

melatonin and $\mathrm{H}_{2} \mathrm{O}_{2}$ in cultured RPE cells, the cells were exposed either to 50 or $100 \mu \mathrm{M}$ melatonin for $48 \mathrm{~h}$ or to various concentrations of $\mathrm{H}_{2} \mathrm{O}_{2}(200,250,300$, or $500 \mu \mathrm{M})$ for $24 \mathrm{~h}$. The results are presented in Figures 1(a) and 1(b). The viability of the RPE cells was assessed using the MTT assay. As illustrated in Figure 1(a), melatonin at the tested concentrations (50 and $100 \mu \mathrm{M}$ ) was generally safe for the ARPE-19 cells (Figure 1(a)). Treatment of the ARPE-19 cells with $\mathrm{H}_{2} \mathrm{O}_{2}$-reduced RPE cell viability is a dose-dependent manner. Exposure to $300 \mu \mathrm{M} \mathrm{H}_{2} \mathrm{O}_{2}$ induced approximately $50 \%$ cell viability loss (Figure $1(\mathrm{~b})$ ). Thus, this concentration (50 and $100 \mu \mathrm{M}$ melatonin; $300 \mu \mathrm{M} \mathrm{H}_{2} \mathrm{O}_{2}$ ) was selected for the subsequent experiments. The ARPE-19 cells were further subjected to melatonin ( 50 and $100 \mu \mathrm{M})$ for $24 \mathrm{~h}$ and were then exposed to $300 \mu \mathrm{M} \mathrm{H}_{2} \mathrm{O}_{2}$ for an additional $24 \mathrm{~h}$ to investigate the protective effects of melatonin on the ARPE- 19 cells. Statistically, melatonin significantly attenuated the reduction in ARPE- 19 viability caused by $\mathrm{H}_{2} \mathrm{O}_{2}$ (Figure $1(\mathrm{c})$ ). Moreover, in order to evaluate the protective effect of melatonin on $\mathrm{H}_{2} \mathrm{O}_{2}$-induced oxidative damage, the study measured LDH release in the ARPE-19 cells following melatonin pretreatment and $\mathrm{H}_{2} \mathrm{O}_{2}$ exposure, and the results showed that $\mathrm{H}_{2} \mathrm{O}_{2}$ treatment induced LDH release, an indicator of cytotoxicity, which was dramatically inhibited by melatonin pretreatment
(Figure 1(d)). These results demonstrate that melatonin protects ARPE-19 cells from $\mathrm{H}_{2} \mathrm{O}_{2}$-induced oxidative damage.

3.2. Luzindole Decreases Protective Effects of Melatonin on RPE Cells against $\mathrm{H}_{2} \mathrm{O}_{2}$ Damage. We evaluate whether the protective effect of melatonin on $\mathrm{H}_{2} \mathrm{O}_{2}$-induced oxidative damage through the melatonin membrane receptor. Next, the cell cultures were challenged with or without luzindole, a melatonin membrane-receptor antagonist, to determine the direct antioxidant versus receptor-mediated effects of melatonin. Luzindole was added to the culture medium at a final concentration of $50 \mu \mathrm{M}$. One hour later, melatonin was added to the culture medium followed by culturing for $48 \mathrm{~h}$, and $\mathrm{H}_{2} \mathrm{O}_{2}$ was then added followed by culturing for $24 \mathrm{~h}$. The ARPE-19 cells cultured with $300 \mu \mathrm{M} \mathrm{H}_{2} \mathrm{O}_{2}$, to which $50 \mu \mathrm{M}$ luzindole was added before melatonin, exhibited a statistically significant decrease in viability compared with cells treated with melatonin alone; luzindole blocked the protective effects of melatonin (Figure 1(e)).

3.3. Melatonin Inhibits $\mathrm{H}_{2} \mathrm{O}_{2}$-Induced Oxidative Stress in ARPE-19 Cells. To evaluate the effect of melatonin on MDA formation, we examined the level of lipid peroxidation by using the TBARS assay. Treatment with $\mathrm{H}_{2} \mathrm{O}_{2}$ resulted in a 


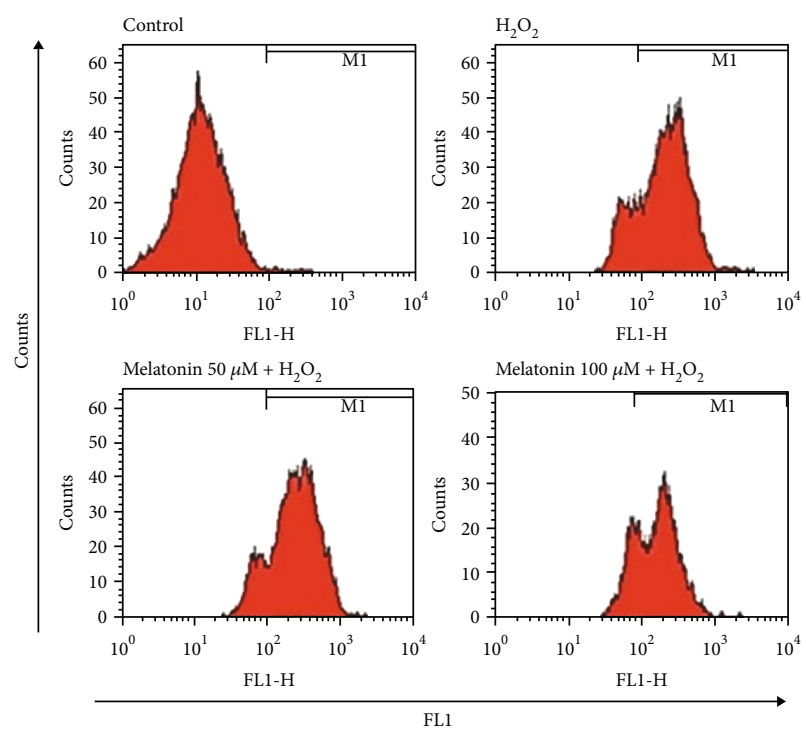

(a)

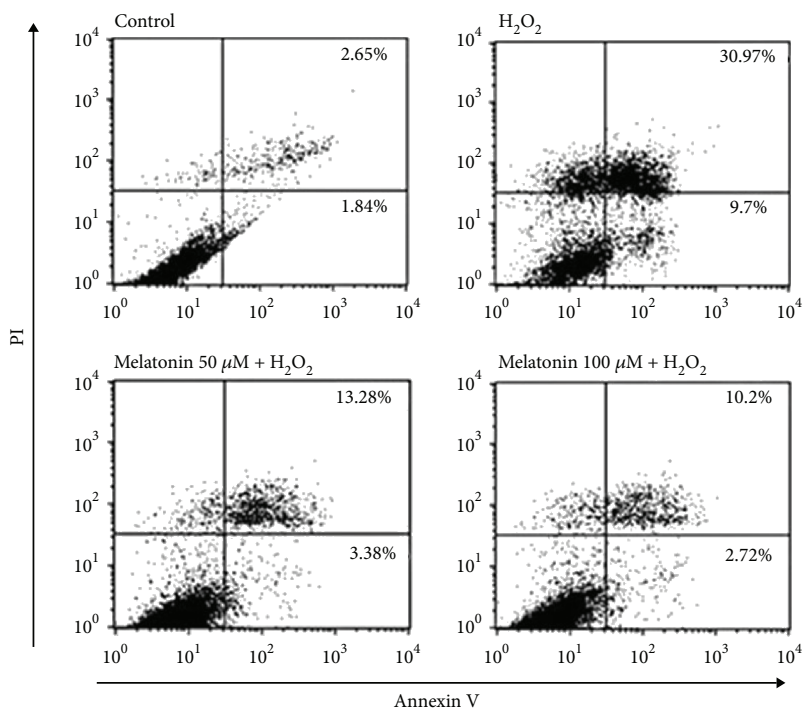

(c)

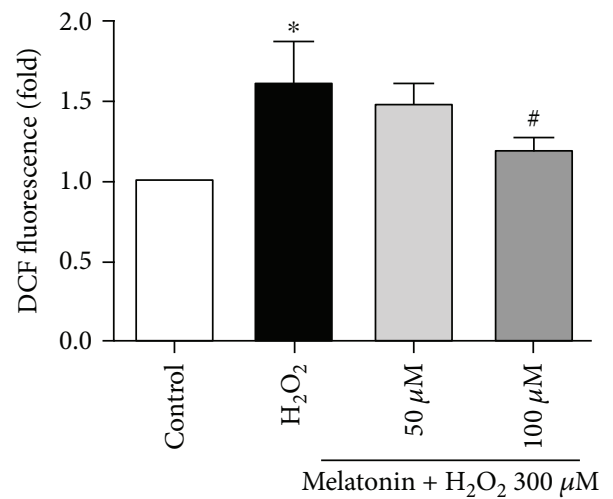

(b)

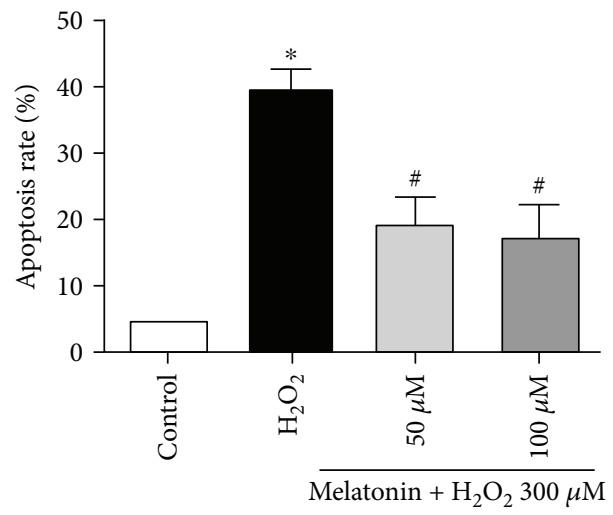

(d)

FIGURE 2: Melatonin inhibits $\mathrm{H}_{2} \mathrm{O}_{2}$-induced ROS production and apoptosis in RPE cells. RPE cells were pretreated with different concentrations of melatonin $(50$ and $100 \mu \mathrm{M})$ for $48 \mathrm{~h}$ and exposed to $300 \mu \mathrm{M} \mathrm{H}_{2} \mathrm{O}_{2}$ for $4 \mathrm{~h} / 24 \mathrm{~h}$. ROS production was determined using the DCFDA assay $(\mathrm{a}, \mathrm{b})$. Cell apoptosis was analyzed with PI and annexin V $(c, d)$. Values are the mean \pm SD. ${ }^{*} p<0.05$ versus the control group and ${ }^{\#} p<0.05$ versus $\mathrm{H}_{2} \mathrm{O}_{2}$-treated cells.

significant increase in MDA levels, which was decreased with melatonin pretreatment (Figure 1(f)). As illustrated in Figures 2(a) and 2(b), $\mathrm{H}_{2} \mathrm{O}_{2}$ increased the ROS level in the ARPE-19 cells and melatonin exhibited a statistically significant inhibitory effect on $\mathrm{H}_{2} \mathrm{O}_{2}$-induced ROS production. Thus, melatonin is shown to suppress lipid peroxidation and ROS generation, and this might account for its protective effect.

3.4. Melatonin Protects ARPE-19 Cells from $\mathrm{H}_{2} \mathrm{O}_{2}$-Induced Apoptosis. To further investigate whether melatonin protects against $\mathrm{H}_{2} \mathrm{O}_{2}$-induced cell death through an antiapoptotic effect, ARPE-19 cell apoptosis was detected using annexin V/PI. As shown in Figures 2(c) and 2(d), the proportion of PI-positive (dead) cells exhibited a statistically significant increase in the ARPE-19 cultures treated with $300 \mu \mathrm{M}$ $\mathrm{H}_{2} \mathrm{O}_{2}$ for $24 \mathrm{~h}$ alone compared with the untreated control cultures. The pretreatment of ARPE-19 cell cultures with 50 and $100 \mu \mathrm{M}$ melatonin for $48 \mathrm{~h}$ before $\mathrm{H}_{2} \mathrm{O}_{2}$ exposure engendered a statistically significant reduction of the proportion of PI-positive (dead) cells compared with cultures exposed to $\mathrm{H}_{2} \mathrm{O}_{2}$ alone. Pretreatment with melatonin reduced 

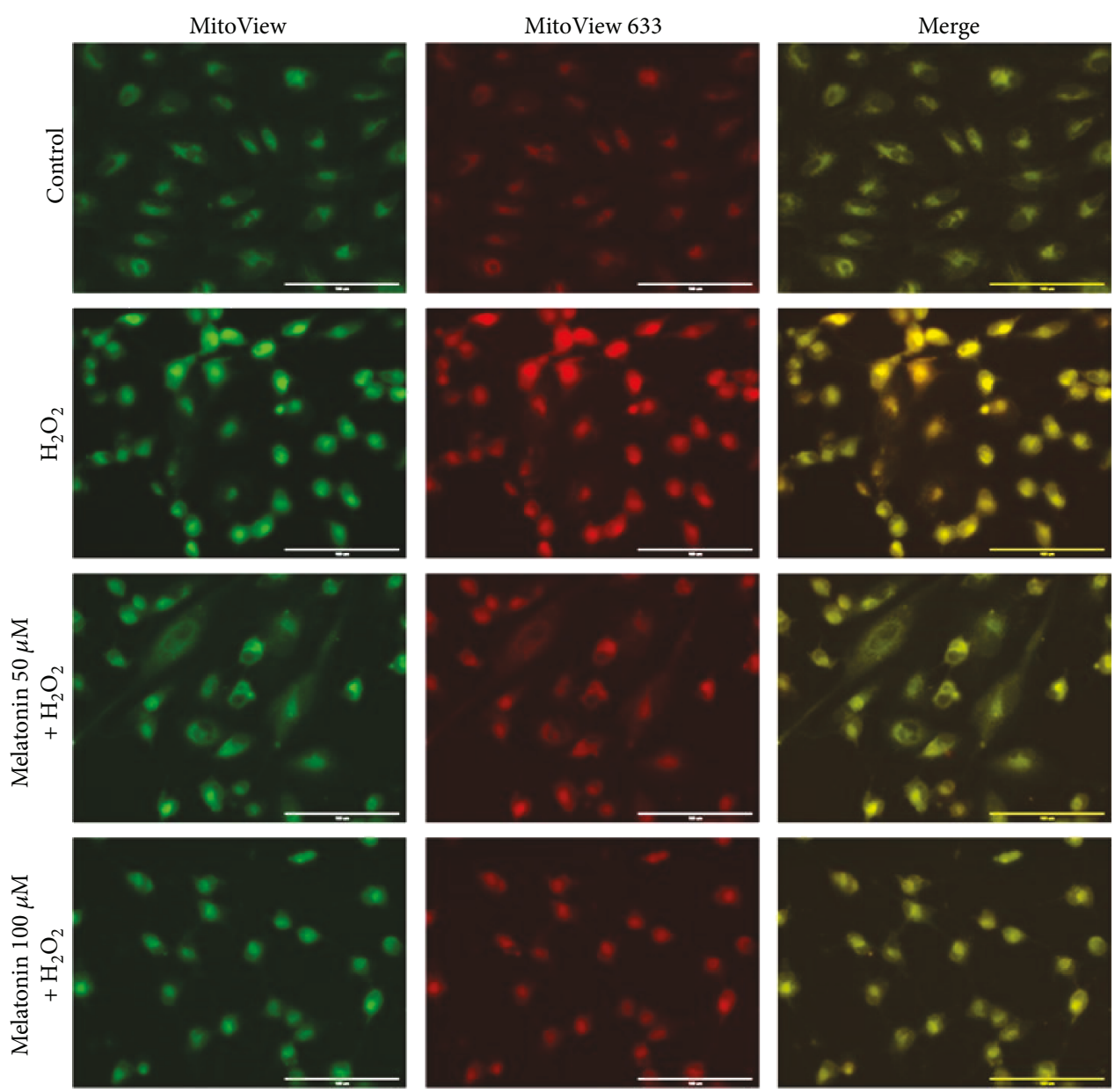

FIGURE 3: Melatonin inhibits $\mathrm{H}_{2} \mathrm{O}_{2}$-induced apoptosis in RPE cells. RPE cells were pretreated with different concentrations of melatonin (50 and $100 \mu \mathrm{M}$ ) for $48 \mathrm{~h}$ and exposed to $300 \mu \mathrm{M} \mathrm{H}_{2} \mathrm{O}_{2}$ for $24 \mathrm{~h}$. Cell apoptosis was analyzed with MitoView dye. Apoptotic cells were stained red in mitochondria because of the mitochondrial membrane potential changing (scale bars are $200 \mu \mathrm{m}$ ).

$\mathrm{H}_{2} \mathrm{O}_{2}$-induced apoptosis; both concentrations of melatonin had a statistically significant effect (Figure 2(d)). Thus, pretreatment with melatonin can protect ARPE-19 cells from $\mathrm{H}_{2} \mathrm{O}_{2}$-induced cell death. The inhibitory effect of melatonin on ARPE-19 cell apoptosis was further confirmed through testing with MitoView 633. As depicted in Figure 3, the mitochondrial membrane potential increased in the ARPE-19 cells treated with $300 \mu \mathrm{M} \mathrm{H}_{2} \mathrm{O}_{2}$ for $24 \mathrm{~h}$ alone compared with the untreated control cultures. This result suggests that the intrinsic pathway is involved in $\mathrm{H}_{2} \mathrm{O}_{2}$-induced apoptotic cell death. However, the ARPE-19 cells pretreated with 50 and $100 \mu \mathrm{M}$ melatonin for $48 \mathrm{~h}$ before $\mathrm{H}_{2} \mathrm{O}_{2}$ exposure for $24 \mathrm{~h}$ exhibited an increased mitochondrial membrane potential compared with the $\mathrm{H}_{2} \mathrm{O}_{2}$ group. This result suggests that melatonin could inhibit $\mathrm{H}_{2} \mathrm{O}_{2}$-induced cell apoptosis in ARPE-19 cells.

The expression of apoptotic protein results demonstrated that 50 and $100 \mu \mathrm{M}$ melatonin inhibited $\mathrm{H}_{2} \mathrm{O}_{2}$-induced caspase 7 cleavage in the ARPE-19 cells (Figures 4(a) and 4(b)). We also measured the protein expression of $\mathrm{Bcl}-2$ and $\mathrm{Bax}$ to determine whether $\mathrm{H}_{2} \mathrm{O}_{2}$ and melatonin administration engendered any changes. The $\mathrm{Bax} / \mathrm{Bcl}-2$ ratio exhibited a statistically significant increase after $\mathrm{H}_{2} \mathrm{O}_{2}$ treatment compared with the control (Figures $4(\mathrm{a})$ and $4(\mathrm{c})$ ), whereas melatonin achieved a statistically significant reduction of the $\mathrm{H}_{2} \mathrm{O}_{2}$ induced increase in the $\mathrm{Bax} / \mathrm{Bcl}-2$ ratio. The $\mathrm{Bax} / \mathrm{Bcl}-2$ ratio is critical for regulating the release of cytochrome $c$ from the mitochondria. Therefore, we assessed the level of cytochrome $c$ in the mitochondria and cytoplasm of the ARPE-19 cells. $\mathrm{H}_{2} \mathrm{O}_{2}$ induced a statistically significant increase in cytochrome $\mathrm{c}$ levels in the cytoplasm but reduced them in the mitochondria (Figures 4(d)-4(f)). By contrast, melatonin reduced cytochrome clevels in the cytoplasm compared with $\mathrm{H}_{2} \mathrm{O}_{2}$ alone. These results indicate that melatonin protects ARPE- 19 cells from $\mathrm{H}_{2} \mathrm{O}_{2}$-induced damage through the antiapoptotic signaling pathway.

3.5. Melatonin Activates Autophagic Process in ARPE-19 Cells. A possible protective function of RPE cells against oxidative stress may involve autophagy, which is the major mechanism for renewing all cytoplasmic parts of postmitotic cells; we thus tested for the effect of autophagy. LC3 processing is a classical autophagic marker, and the ratio of conversion from LC3-I to LC3-II is closely correlated with the extent of autophagosome formation. We evaluated the expression of LC3-II autophagic markers. In Figures 5(a)-5(c), it was indicated that pretreatment 


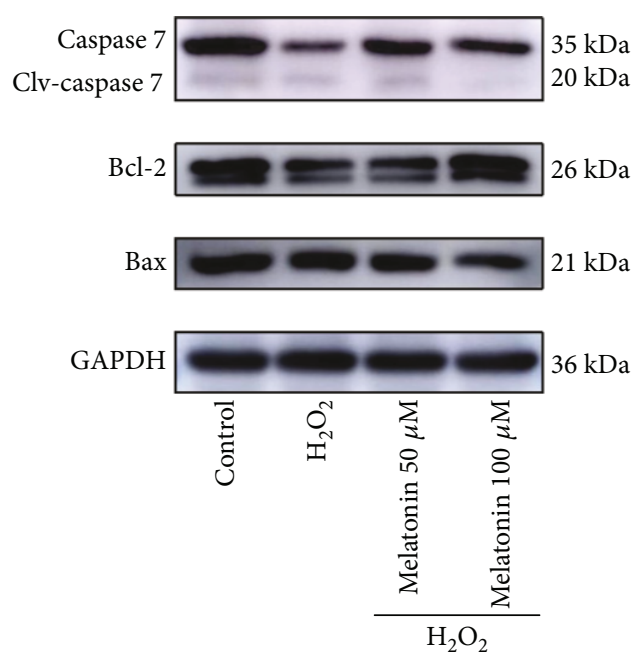

(a)

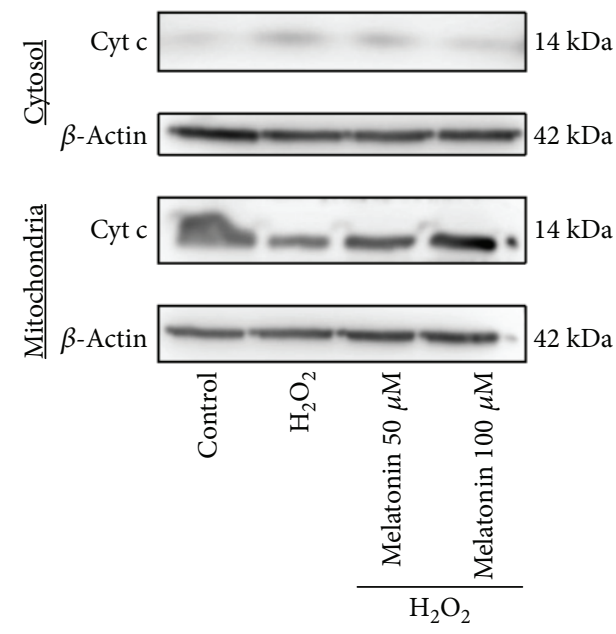

(d)

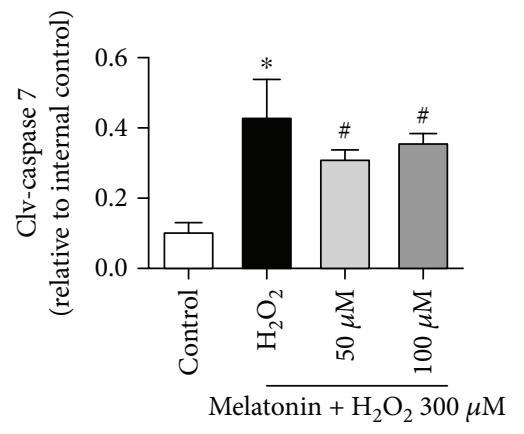

(b)

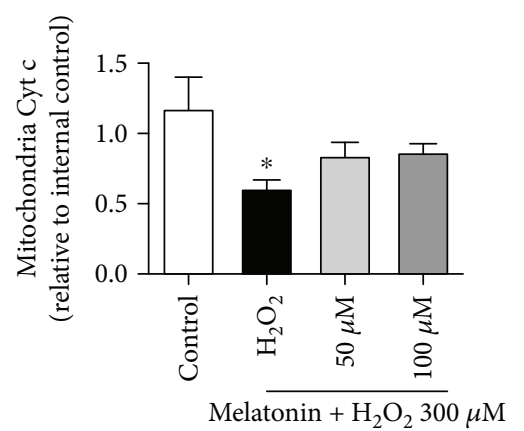

(e)

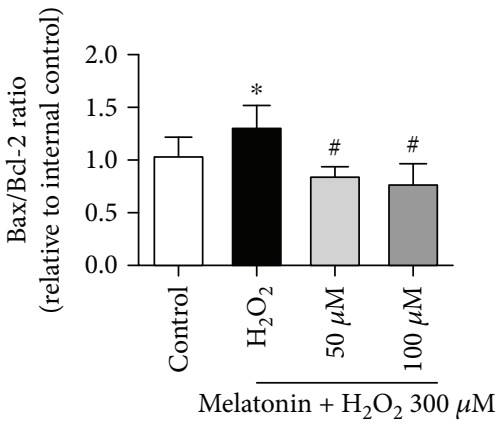

(c)

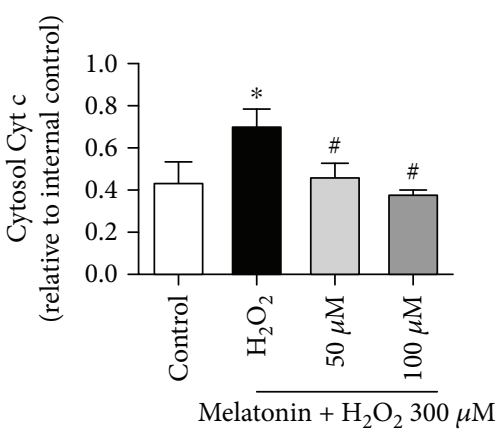

(f)

FIGURE 4: Melatonin inhibits $\mathrm{H}_{2} \mathrm{O}_{2}$-induced apoptosis-related protein expression in RPE cells. ARPE-19 cells were pretreated with the different concentrations of melatonin $(50$ and $100 \mu \mathrm{M})$ for $48 \mathrm{~h}$ and exposed to $300 \mu \mathrm{M} \mathrm{H}_{2} \mathrm{O}_{2}$ for 24 h. Expression levels of apoptosisrelated proteins (caspase 7, cleavage-caspase 7, Bcl-2, Bax, and Cyt c) are displayed in (a-f). Protein expression was calculated from densitometry absorbance values of three separate experiments after they were corrected for GAPDH/ $\beta$-actin expression to obtain equal loading. Values are the mean \pm SD. ${ }^{*} p<0.05$ versus the control group and ${ }^{\#} p<0.05$ versus $\mathrm{H}_{2} \mathrm{O}_{2}$-treated cells.

with 50 and $100 \mu \mathrm{M}$ melatonin for $48 \mathrm{~h}$ before $\mathrm{H}_{2} \mathrm{O}_{2}$ exposure for $24 \mathrm{~h}$ in the ARPE-19 cells increased the expression of LC3-II and the LC3-II/LC3-I ratio, thereby providing evidence that melatonin enhances the autophagic process in $\mathrm{H}_{2} \mathrm{O}_{2}$-treated ARPE-19 cells. In the cotreated $\mathrm{H}_{2} \mathrm{O}_{2}$ and melatonin groups, LC3-II levels exhibited a statistically significant increase compared with the $\mathrm{H}_{2} \mathrm{O}_{2}$-treated group (Figure 5(b)). Moreover, Beclin-1 also plays an important role in autophagosome formation and it is therefore considered an autophagic marker for the activation of autophagosomes. We evaluated the expression of the Beclin-1. Beclin-1 levels exhibited a statistically significant decrease in the cells treated with $300 \mu \mathrm{M} \mathrm{H}_{2} \mathrm{O}_{2}$. Cells cotreated with $\mathrm{H}_{2} \mathrm{O}_{2}$ and melatonin demonstrated a statistically significant increase in Beclin-1 levels compared with $\mathrm{H}_{2} \mathrm{O}_{2}$-treated cells (Figures 5(a) and 5(d)). As displayed in Figure 5(a), melatonin also downregulated the expression of the autophagy- related protein p62 expression. Melatonin caused a statistically significant decrease in p62 levels compared with the control group (Figures 5(e) and 5(f)). As shown in Figure $5(\mathrm{~g})$, the treatment concomitantly reduced mTOR phosphorylation. Cells cotreated with $\mathrm{H}_{2} \mathrm{O}_{2}$ and melatonin demonstrated a statistically significant decreased mTOR phosphorylation levels compared with $\mathrm{H}_{2} \mathrm{O}_{2}$-treated cells. However, melatonin did not cause a statistically significant decrease in ULK-1 phosphorylation levels compared with the $\mathrm{H}_{2} \mathrm{O}_{2}$-treated cells (Figure 5(h)). These findings indicated melatonin pretreatment can increase the autophagic process in ARPE-19 and decrease $\mathrm{H}_{2} \mathrm{O}_{2}$-induced cell death.

\section{Discussion}

Accumulating evidence reveals that the oxidative stress of RPE cells is a crucial aspect of the pathophysiology of AMD 


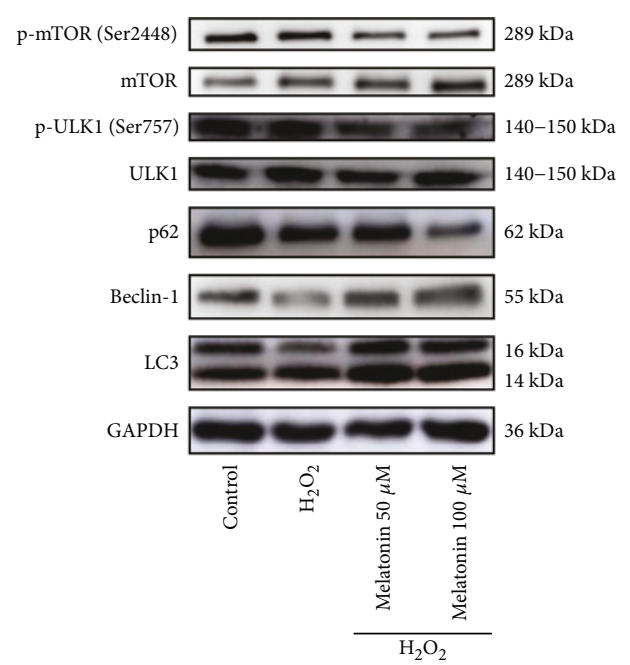

(a)

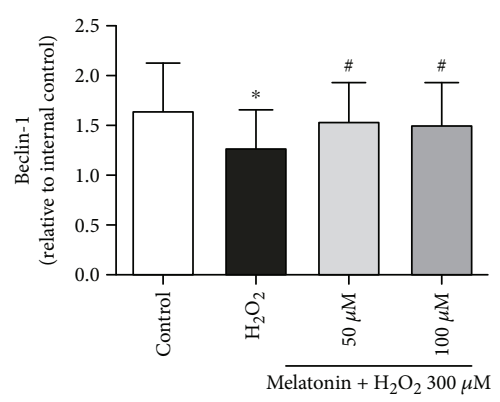

(d)

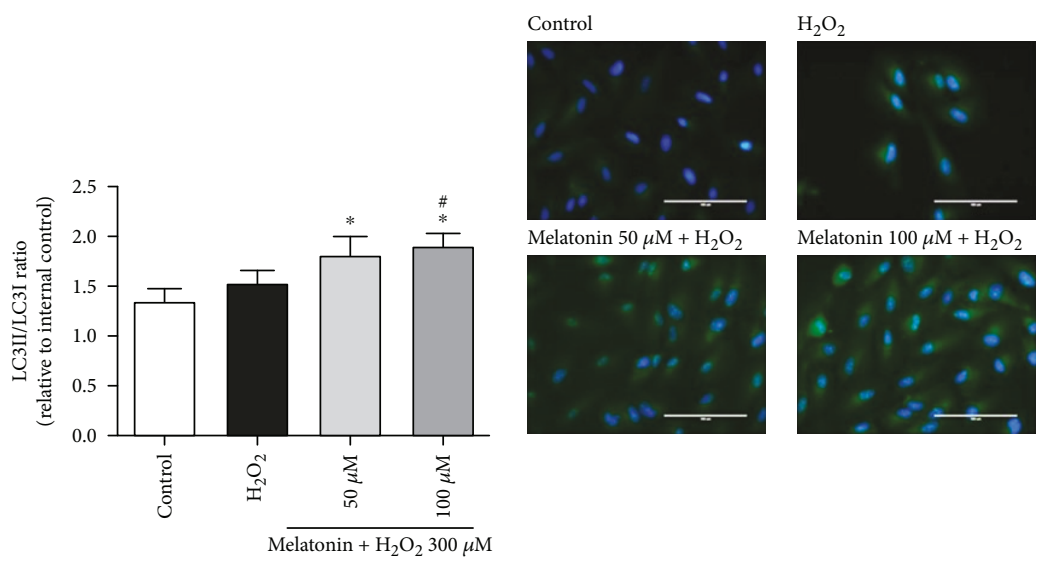

(b) (c)

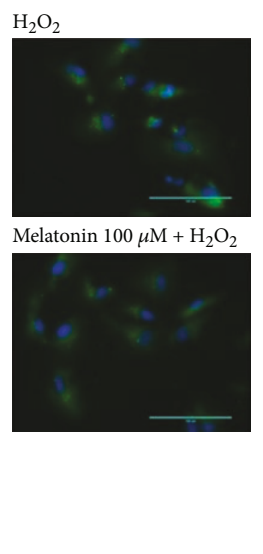

(e)

(f)

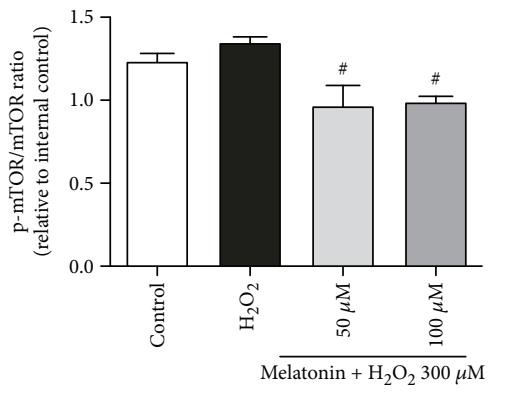

(g)

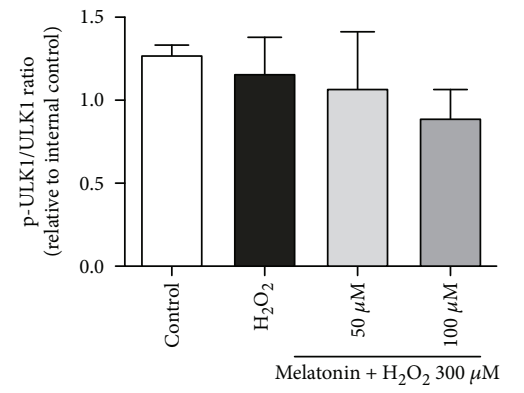

(h)

FIgURE 5: Melatonin increases autophagy in RPE cells. ARPE-19 cells were pretreated with melatonin (50 and $100 \mu \mathrm{M})$ for $48 \mathrm{~h}$ and exposed to $300 \mu \mathrm{M} \mathrm{H}_{2} \mathrm{O}_{2}$ for $24 \mathrm{~h}$. Expression levels of proteins are presented in (a-h). Expression levels of LC3 (a, b). LC3 was determined using ICC in ARPE-19 cells (magnification, $\times 40$ ) (c). Expression levels of Beclin-1 (d). Expression levels of p62 (e). p62 was determined using ICC in ARPE-19 cells (magnification, $\times 40$ ) (f). Expression levels of mTOR and p-mTOR (Ser2448) (g). Expression levels of ULK1 and p-ULK1 (Ser757) (h). Protein expression was calculated from densitometry absorbance values after correction for GAPDH expression to obtain equal loading. Values are the mean \pm SD. ${ }^{*} p<0.05$ versus the control group and ${ }^{\#} p<0.05$ versus $\mathrm{H}_{2} \mathrm{O}_{2}$-treated cells (scale bars are $100 \mu \mathrm{m}$ ).

[39]. Therefore, studies have focused on designing approaches to protect RPE cells from oxidative stress as therapeutic options for AMD. Exposure to $\mathrm{H}_{2} \mathrm{O}_{2}$ is used as a common model to convey the oxidative stress susceptibility and antioxidant activity of RPE cells [16, 32, 34]. Abundant natural products, particularly flavonoids, confer adaptive survival responses under various adverse environmental conditions through inhibiting oxidative stress [40] [41, 42]. In this study, we observed that the viability of ARPE-19 cells that were exposed to $300 \mu \mathrm{M} \mathrm{H}_{2} \mathrm{O}_{2}$ decreased by approximately $30 \%$, but melatonin pretreatment significantly inhibited $\mathrm{H}_{2} \mathrm{O}_{2}$-induced damage and increased cell viability. However, 


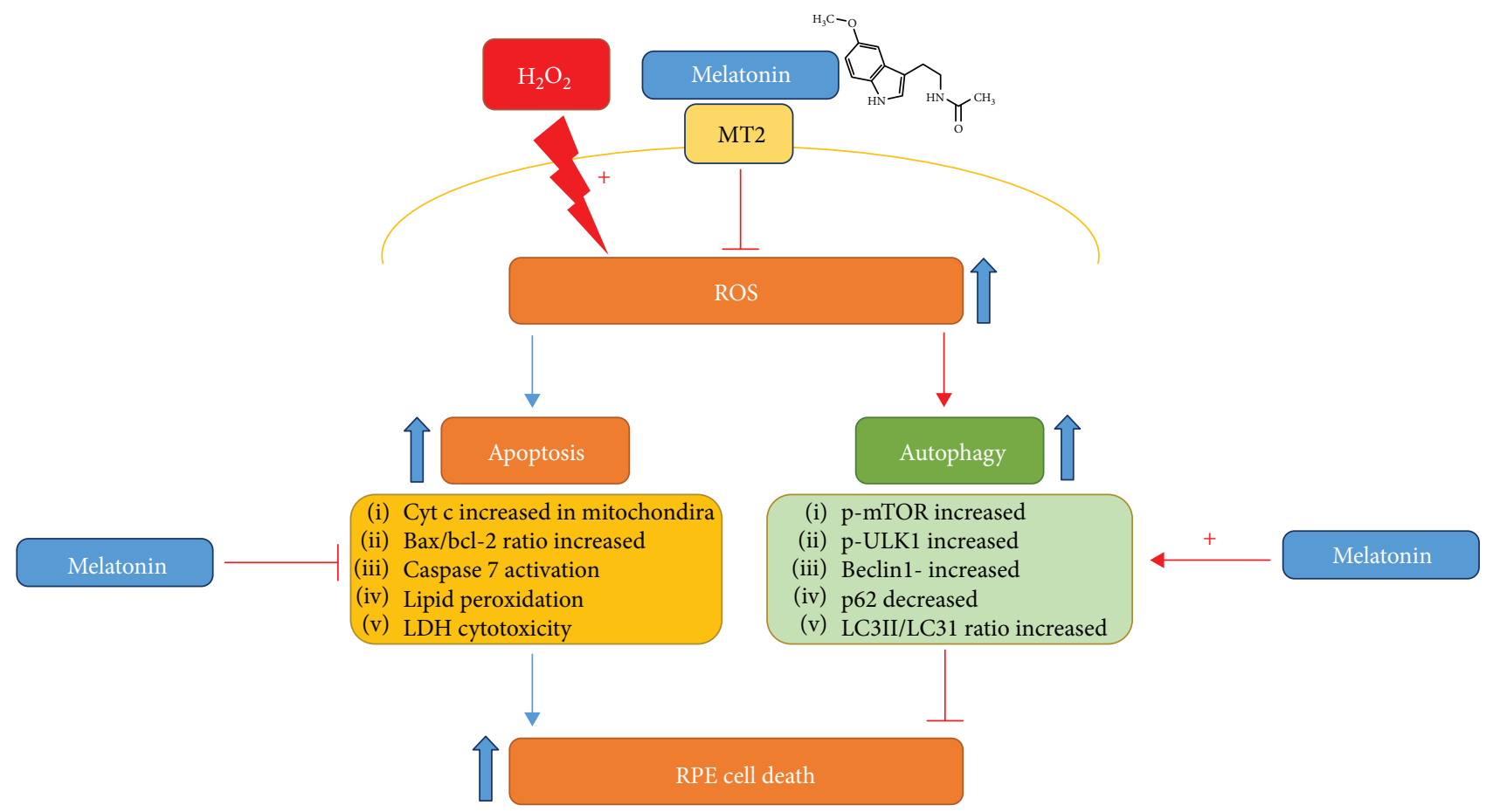

FIGURE 6: Summary of effects of melatonin against $\mathrm{H}_{2} \mathrm{O}_{2}$-induced oxidative damage in RPE cells. Melatonin inhibits $\mathrm{H}_{2} \mathrm{O}_{2}$-induced RPE cell damage, decreases the apoptosis rate, increases mitochondrial membrane potential, decreases caspase activation, and mediates the autophagy pathway in ARPE-19 cells.

MDA reflects oxidative damage in RPE cells. Therefore, to slow the progress and development of early AMD resulting from oxidative damage, it is critical to protect RPE cells by reducing ROS and MDA formation [43-45]. The current study indicated that the exposure of ARPE-19 cells to $\mathrm{H}_{2} \mathrm{O}_{2}$ resulted in increases in ROS and MDA generation, but these effects were significantly ameliorated by treatment with melatonin.

Previous research also reported that secretion levels of melatonin decrease with age, and a particularly demonstrable decrease in circulating melatonin was reported in patients with AMD [28]. Previous studies have demonstrated that melatonin protects RPE cells against blue light and $\mathrm{H}_{2} \mathrm{O}_{2}$ damage in vitro and against oxidative stress [32, 34, 35]. Melatonin is a well-known antioxidant and endogenous ROS scavenger and has a higher antioxidant capacity than that of other antioxidants such as vitamin E $[30,46]$ It may also have protective effects on different types of retinal cells including RPE cells and photoreceptors [46]. In a diabetes study, researchers determined that endogenous and exogenous melatonin may influence metabolic disturbances not only by regulating insulin secretion but also by providing protection against ROS [47]. In the present work, melatonin provides protection against $\mathrm{H}_{2} \mathrm{O}_{2}$-induced ROS. $\mathrm{H}_{2} \mathrm{O}_{2}$ induced RPE cell apoptosis was a well-known study model for drug discovery $[16,48-50]$. In the present work, our results demonstrate that $\mathrm{H}_{2} \mathrm{O}_{2}$ can lead to cell apoptosis through increasing apoptosis-related proteins (Bax, Cyt c, and caspase 7) in ARPE-19 cells, but this process was significantly reduced by melatonin. These results suggest that melatonin prevents $\mathrm{H}_{2} \mathrm{O}_{2}$-stimulated cell apoptosis in ARPE-19 cells, which may be strongly related to the antiapoptotic and antioxidative effects of melatonin.

One novel and major finding of this study is that melatonin could reduce $\mathrm{H}_{2} \mathrm{O}_{2}$-induced $\mathrm{RPE}$ damage through autophagy. The increased autophagy significantly reduced apoptotic cytotoxicity, suggesting that ROS-activated autophagy was cytoprotective against apoptosis [51]. Autophagy is crucial for the maintenance of homeostasis of RPE cells because it removes dysfunctional organelles and proteins [52-54]. Insufficient digestion because of impaired autophagy in the retinal pigment epithelium causes an accumulation of damaged organelles and toxic proteins, which can contribute to RPE dysfunction and has been associated with the pathogenesis of AMD $[55,56]$. Autophagy is regulated by multiple signaling pathways, in which AMPK-mTOR one of the pathways plays an important role in the regulatory process. The mTOR signaling is a negative regulator of autophagy [57]. The level of conversion of LC3-I to LC3-II can be used as an indicator for autophagic activity. The p62 protein is selectively incorporated into autophagosomes through direct binding to LC3-II and efficiently degraded in the autolysosome. Accordingly, the total p62 expression level is negatively correlated with autophagy [58]. Beclin-1 acts during the initiation stage of autophagy by forming the isolation membrane, a doublemembrane structure that engulfs cytoplasmic material to form the autophagosome [58]. A previous study indicates a potential function of melatonin in autophagy regulation during oxidative stress [59]. In this study, we determined that melatonin inhibited mTOR and increased autophagic markers (LC3-II and Beclin-1) in unison and promoted autophagy. This finding implies that ROS regulated autophagy 
in the ARPE-19 cells by downregulating mTOR and upregulating LC3-II and Beclin-1, which increased the potency of melatonin for protecting ARPE-19 cells from oxidative stress-induced cell death. Therefore, melatonin uptake may be beneficial for protecting RPE cells from $\mathrm{H}_{2} \mathrm{O}_{2}$-induced oxidative damage associated with retinal diseases.

We discovered that melatonin mediated autophagy and inhibited $\mathrm{H}_{2} \mathrm{O}_{2}$-induced $\mathrm{ROS}$ accumulation and lipid peroxidation in ARPE-19 cells, which could explain the significant protective effect of melatonin on RPE cells. In addition, we discovered these effects of melatonin were blocked by luzindole. Thus, cytoprotection of melatonin might be associated with melatonin receptor-mediated effects, which is consistent with the findings of previous research [34].

\section{Conclusion}

In conclusion, melatonin has protective effects against $\mathrm{H}_{2} \mathrm{O}_{2}-$ induced retinal cell death. Melatonin inhibits $\mathrm{H}_{2} \mathrm{O}_{2}$-induced RPE cell damage, decreases the apoptosis rate, increases mitochondrial membrane potential, decreases caspase activation, and mediates the autophagy pathway in ARPE-19 cells (Figure 6). These findings have therapeutic implications for AMD and related inflammatory diseases.

\section{Data Availability}

The data used to support the findings of this study are available from the corresponding author upon request.

\section{Conflicts of Interest}

The authors declare that they have no competing interests.

\section{Authors' Contributions}

Chih-Chao Chang and Tien-Yi Huang contributed equally to this work.

\section{Acknowledgments}

This study was supported by the China Ministry of Science and Technology (Grant nos. MOST106-2320-B-038-064MY3, MOST103-2313-B-038-003-MY3, and NSC102-2313B-038-001) and the Council of Agriculture, Taiwan, Republic of China (Grant no. 106AS-16.4.1-ST-a4).

\section{Supplementary Materials}

Supplementary material contains the experimental protocol in revised articles. Figure S1: the experimental protocol for ARPE-19 cells. (Supplementary Materials)

\section{References}

[1] U. Schmidt-Erfurth, P. K. Kaiser, J. F. Korobelnik et al., "Intravitreal aflibercept injection for neovascular age-related macular degeneration: ninety-six-week results of the VIEW studies," Ophthalmology, vol. 121, no. 1, pp. 193-201, 2014.
[2] K. M. Gehrs, D. H. Anderson, L. V. Johnson, and G. S. Hageman, "Age-related macular degeneration-emerging pathogenetic and therapeutic concepts," Annals of Medicine, vol. 38, no. 7, pp. 450-471, 2006.

[3] R. Klein, C. F. Chou, B. E. Klein, X. Zhang, S. M. Meuer, and J. B. Saaddine, "Prevalence of age-related macular degeneration in the US population," Archives of Ophthalmology, vol. 129, no. 1, pp. 75-80, 2011.

[4] M. van Lookeren Campagne, J. LeCouter, B. L. Yaspan, and W. Ye, "Mechanisms of age-related macular degeneration and therapeutic opportunities," The Journal of Pathology, vol. 232, no. 2, pp. 151-164, 2014.

[5] H. Yu, X. Zou, L. Peng et al., "Effect of soluble inducible costimulator level and its polymorphisms on age-related macular degeneration," DNA and Cell Biology, vol. 32, no. 12, pp. 717-721, 2013.

[6] P. S. Mettu, A. R. Wielgus, S. S. Ong, and S. W. Cousins, "Retinal pigment epithelium response to oxidant injury in the pathogenesis of early age-related macular degeneration," Molecular Aspects of Medicine, vol. 33, no. 4, pp. 376-398, 2012.

[7] S. Beatty, H. H. Koh, M. Phil, D. Henson, and M. Boulton, "The role of oxidative stress in the pathogenesis of agerelated macular degeneration," Survey of Ophthalmology, vol. 45, no. 2, pp. 115-134, 2000.

[8] R. E. Pacifici and K. J. Davies, "Protein, lipid and DNA repair systems in oxidative stress: the free-radical theory of aging revisited," Gerontology, vol. 37, no. 1-3, pp. 166-180, 1991.

[9] J. M. Seddon, U. A. Ajani, R. D. Sperduto et al., "Dietary carotenoids, vitamins A, C, and E, and advanced age-related macular degeneration: Eye Disease Case-Control Study Group," JAMA, vol. 272, no. 18, pp. 1413-1420, 1994.

[10] M. Valko, D. Leibfritz, J. Moncol, M. T. D. Cronin, M. Mazur, and J. Telser, "Free radicals and antioxidants in normal physiological functions and human disease," The International Journal of Biochemistry \& Cell Biology, vol. 39, no. 1, pp. 4484, 2007.

[11] K. Wang, Y. Jiang, W. Wang, J. Ma, and M. Chen, "Escin activates AKT-Nrf2 signaling to protect retinal pigment epithelium cells from oxidative stress," Biochemical and Biophysical Research Communications, vol. 468, no. 4, pp. 541-547, 2015.

[12] G. F. Cao, Y. Liu, W. Yang et al., "Rapamycin sensitive mTOR activation mediates nerve growth factor (NGF) induced cell migration and pro-survival effects against hydrogen peroxide in retinal pigment epithelial cells," Biochemical and Biophysical Research Communications, vol. 414, no. 3, pp. 499-505, 2011.

[13] J. Yao, H. E. Bi, Y. Sheng et al., "Ultraviolet (UV) and hydrogen peroxide activate ceramide-ER stress-AMPK signaling axis to promote retinal pigment epithelium (RPE) cell apoptosis," International Journal of Molecular Sciences, vol. 14, no. 5, pp. 10355-10368, 2013.

[14] V. M. Di Mambro, M. F. Borin, and M. J. Fonseca, "Topical formulations with superoxide dismutase: influence of formulation composition on physical stability and enzymatic activity," Journal of Pharmaceutical and Biomedical Analysis, vol. 32, no. 1, pp. 97-105, 2003.

[15] F. A. Shamsi, I. A. Chaudhry, M. E. Boulton, and A. A. al-Rajhi, "L-carnitine protects human retinal pigment epithelial cells from oxidative damage," Current Eye Research, vol. 32, no. 6, pp. 575-584, 2007. 
[16] C. Zhu, Y. Dong, H. Liu, H. Ren, and Z. Cui, "Hesperetin protects against $\mathrm{H}_{2} \mathrm{O}_{2}$-triggered oxidative damage via upregulation of the Keap1-Nrf2/HO-1 signal pathway in ARPE-19 cells," Biomedicine \& Pharmacotherapy, vol. 88, pp. 124-133, 2017.

[17] M. Nita and A. Grzybowski, "The role of the reactive oxygen species and oxidative stress in the pathomechanism of the age-related ocular diseases and other pathologies of the anterior and posterior eye segments in adults," Oxidative Medicine and Cellular Longevity, vol. 2016, Article ID 3164734, 23 pages, 2016.

[18] M. H. Reisenhofer, J. M. Balmer, and V. Enzmann, "What can pharmacological models of retinal degeneration tell us?," Current Molecular Medicine, vol. 17, no. 2, pp. 100-107, 2017.

[19] A. Jourdain and J. C. Martinou, "Mitochondrial outermembrane permeabilization and remodelling in apoptosis," The International Journal of Biochemistry \& Cell Biology, vol. 41, no. 10, pp. 1884-1889, 2009.

[20] J. K. Brunelle and A. Letai, "Control of mitochondrial apoptosis by the Bcl-2 family," Journal of Cell Science, vol. 122, no. 4, pp. 437-441, 2009.

[21] J. Blasiak, M. Piechota, E. Pawlowska, M. Szatkowska, E. Sikora, and K. Kaarniranta, "Cellular senescence in agerelated macular degeneration: can autophagy and DNA damage response play a role?," Oxidative Medicine and Cellular Longevity, vol. 2017, Article ID 5293258, 15 pages, 2017.

[22] J. Y. Kim, H. Zhao, J. Martinez et al., "Noncanonical autophagy promotes the visual cycle," Cell, vol. 154, no. 2, pp. 365376, 2013.

[23] S. K. Mitter, H. V. Rao, X. Qi et al., "Autophagy in the retina: a potential role in age-related macular degeneration," Advances in Experimental Medicine and Biology, vol. 723, pp. 83-90, 2012.

[24] N. Mizushima and M. Komatsu, "Autophagy: renovation of cells and tissues," Cell, vol. 147, no. 4, pp. 728-741, 2011.

[25] B. Claustrat, J. Brun, and G. Chazot, "The basic physiology and pathophysiology of melatonin," Sleep Medicine Reviews, vol. 9, no. 1, pp. 11-24, 2005.

[26] S. R. Pandi-Perumal, V. Srinivasan, G. J. M. Maestroni, D. P. Cardinali, B. Poeggeler, and R. Hardeland, "Melatonin: nature's most versatile biological signal?," The FEBS Journal, vol. 273, no. 13, pp. 2813-2838, 2006.

[27] R. Liu, H. L. Wang, M. J. Deng et al., "Melatonin inhibits reactive oxygen species-driven proliferation, epithelial-mesenchymal transition, and vasculogenic mimicry in oral cancer," Oxidative Medicine and Cellular Longevity, vol. 2018, Article ID 3510970, 13 pages, 2018.

[28] R. Rosen, D. N. Hu, V. Perez et al., "Urinary 6-sulfatoxymelatonin level in age-related macular degeneration patients," Molecular Vision, vol. 15, pp. 1673-1679, 2009.

[29] D. X. Tan, R. Reiter, L. Manchester et al., "Chemical and physical properties and potential mechanisms: melatonin as a broad spectrum antioxidant and free radical scavenger," Current Topics in Medicinal Chemistry, vol. 2, no. 2, pp. 181197, 2002.

[30] R. Brennan, J. E. Jan, and C. J. Lyons, "Light, dark, and melatonin: emerging evidence for the importance of melatonin in ocular physiology," Eye, vol. 21, no. 7, pp. 901-908, 2007.

[31] V. Srinivasan, "Melatonin oxidative stress and neurodegenerative diseases," Indian Journal of Experimental Biology, vol. 40, no. 6, pp. 668-679, 2002.
[32] F. Q. Liang, L. Green, C. Wang, R. Alssadi, and B. F. Godley, "Melatonin protects human retinal pigment epithelial (RPE) cells against oxidative stress," Experimental Eye Research, vol. 78, no. 6, pp. 1069-1075, 2004.

[33] Y. Fu, M. Tang, Y. Fan, H. Zou, X. Sun, and X. Xu, "Anti-apoptotic effects of melatonin in retinal pigment epithelial cells," Frontiers in Bioscience, vol. 17, no. 1, pp. 1461-1468, 2012.

[34] R. B. Rosen, D. N. Hu, M. Chen, S. McCormick, J. Walsh, and J. E. Roberts, "Effects of melatonin and its receptor antagonist on retinal pigment epithelial cells against hydrogen peroxide damage," Molecular Vision, vol. 18, pp. 1640-1648, 2012.

[35] M. Argun, L. Tök, A. C. Uğuz, Ö. Çelik, Ö. Y. Tök, and M. Naziroğlu, "Melatonin and amfenac modulate calcium entry, apoptosis, and oxidative stress in ARPE-19 cell culture exposed to blue light irradiation $(405 \mathrm{~nm}), "$ Eye, vol. 28, no. 6, pp. 752-760, 2014.

[36] S. Y. W. Shiu, B. Pang, C. W. Tam, and K.-M. Yao, "Signal transduction of receptor-mediated antiproliferative action of melatonin on human prostate epithelial cells involves dual activation of $\mathrm{G} \alpha_{\mathrm{s}}$ and $\mathrm{G} \alpha_{\mathrm{q}}$ proteins," Journal of Pineal Research, vol. 49, no. 3, pp. 301-311, 2010.

[37] M. Alizadeh, M. Wada, C. M. Gelfman, J. T. Handa, and L. M. Hjelmeland, "Downregulation of differentiation specific gene expression by oxidative stress in ARPE-19 cells," Investigative Ophthalmology \& Visual Science, vol. 42, no. 11, pp. 27062713, 2001.

[38] P. P. Van Veldhoven, "Biochemistry and genetics of inherited disorders of peroxisomal fatty acid metabolism," Journal of Lipid Research, vol. 51, no. 10, pp. 2863-2895, 2010.

[39] Z. Yildirim, N. I. Ucgun, and F. Yildirim, "The role of oxidative stress and antioxidants in the pathogenesis of age-related macular degeneration," Clinics, vol. 66, no. 5, pp. 743-746, 2011.

[40] W. Chen, Z. Jia, H. Zhu, K. Zhou, Y. Li, and H. P. Misra, "Ethyl pyruvate inhibits peroxynitrite-induced DNA damage and hydroxyl radical generation: implications for neuroprotection," Neurochemical Research, vol. 35, no. 2, pp. 336-342, 2010.

[41] W. Chen, J. Zhuang, Y. Li, Y. Shen, and X. Zheng, "Myricitrin protects against peroxynitrite-mediated DNA damage and cytotoxicity in astrocytes," Food Chemistry, vol. 141, no. 2, pp. 927-933, 2013.

[42] H. S. Wei Chen, Z. Huang, L. Feng, and H. Nie, "Neuroprotective effect of raspberry extract by inhibiting peroxynitriteinduced DNA damage and hydroxyl radical formation," Food Research International, vol. 49, no. 1, pp. 22-26, 2012.

[43] Y. Totan, R. Yağc1, Y. Bardak et al., "Oxidative macromolecular damage in age-related macular degeneration," Current Eye Research, vol. 34, no. 12, pp. 1089-1093, 2009.

[44] M. Bergmann, F. Holz, and J. Kopitz, "Lysosomal stress and lipid peroxidation products induce VEGF-121 and VEGF165 expression in ARPE-19 cells," Graefe's Archive for Clinical and Experimental Ophthalmology, vol. 249, no. 10, pp. 14771483, 2011.

[45] J. Wang, Z. Sun, J. Shen et al., "Octreotide protects the mouse retina against ischemic reperfusion injury through regulation of antioxidation and activation of NF- $\kappa \mathrm{B}$," Oxidative Medicine and Cellular Longevity, vol. 2015, Article ID 970156, 11 pages, 2015.

[46] G. Tosini, K. Baba, C. K. Hwang, and P. M. Iuvone, "Melatonin: an underappreciated player in retinal physiology and 
pathophysiology," Experimental Eye Research, vol. 103, pp. 82-89, 2012.

[47] J. Espino, A. B. Rodriguez, and J. A. Pariente, "Melatonin and oxidative stress in the diabetic state: clinical implications and potential therapeutic applications," Current Medicinal Chemistry, vol. 25, 2018.

[48] X. Xie, J. Feng, Z. Kang et al., "Taxifolin protects RPE cells against oxidative stress-induced apoptosis," Molecular Vision, vol. 23, pp. 520-528, 2017.

[49] V. Pittalà, A. Fidilio, F. Lazzara et al., "Effects of novel nitric oxide-releasing molecules against oxidative stress on retinal pigmented epithelial cells," Oxidative Medicine and Cellular Longevity, vol. 2017, Article ID 1420892, 11 pages, 2017.

[50] R. E. King, K. D. Kent, and J. A. Bomser, "Resveratrol reduces oxidation and proliferation of human retinal pigment epithelial cells via extracellular signal-regulated kinase inhibition," Chemico-Biological Interactions, vol. 151, no. 2, pp. 143-149, 2005.

[51] G. Y. Liu, X. X. Jiang, X. Zhu et al., "ROS activates JNKmediated autophagy to counteract apoptosis in mouse mesenchymal stem cells in vitro," Acta Pharmacologica Sinica, vol. 36, no. 12, pp. 1473-1479, 2015.

[52] J. Lee, S. Giordano, and J. Zhang, "Autophagy, mitochondria and oxidative stress: cross-talk and redox signalling," The Biochemical Journal, vol. 441, no. 2, pp. 523-540, 2012.

[53] A. M. Choi, S. W. Ryter, and B. Levine, "Autophagy in human health and disease," The New England Journal of Medicine, vol. 368, no. 19, pp. 1845-1846, 2013.

[54] Q. Bo, S. Ma, Q. Han, F. E. Wang, X. Li, and Y. Zhang, "Role of autophagy in photoreceptor cell survival and death," Critical Reviews in Eukaryotic Gene Expression, vol. 25, no. 1, pp. 2332, 2015.

[55] D. Pauleikhoff, B. Kirchhof, B. Bertram et al., "New aspects in the treatment of neovascular age-related macular degeneration: the criteria of re-treatment with the anti-VEGF therapy," Der Ophthalmologe, vol. 108, no. 1, pp. 85-90, 2011.

[56] S. K. Mitter, C. Song, X. Qi et al., "Dysregulated autophagy in the RPE is associated with increased susceptibility to oxidative stress and AMD," Autophagy, vol. 10, no. 11, pp. 1989-2005, 2014.

[57] Y. C. Kim and K. L. Guan, "mTOR: a pharmacologic target for autophagy regulation," The Journal of Clinical Investigation, vol. 125, no. 1, pp. 25-32, 2015.

[58] N. Mizushima, T. Yoshimori, and B. Levine, "Methods in mammalian autophagy research," Cell, vol. 140, no. 3, pp. 313-326, 2010.

[59] A. Coto-Montes, J. A. Boga, S. Rosales-Corral, L. FuentesBroto, D. X. Tan, and R. J. Reiter, "Role of melatonin in the regulation of autophagy and mitophagy: a review," Molecular and Cellular Endocrinology, vol. 361, no. 1-2, pp. 12-23, 2012. 


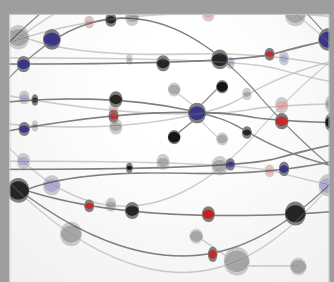

The Scientific World Journal
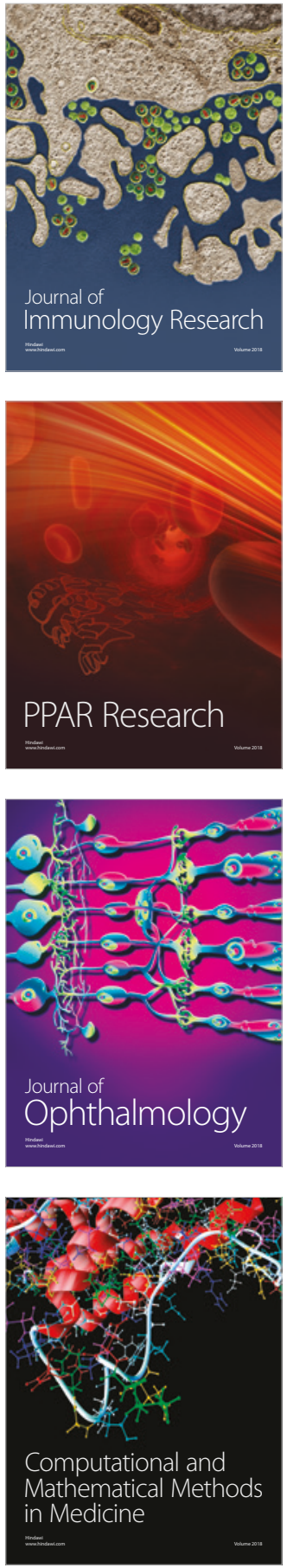

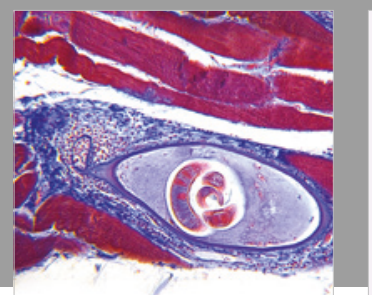

Gastroenterology Research and Practice

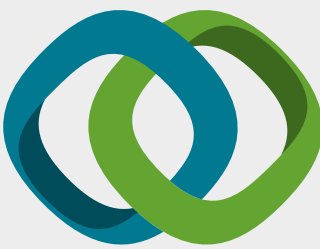

\section{Hindawi}

Submit your manuscripts at

www.hindawi.com
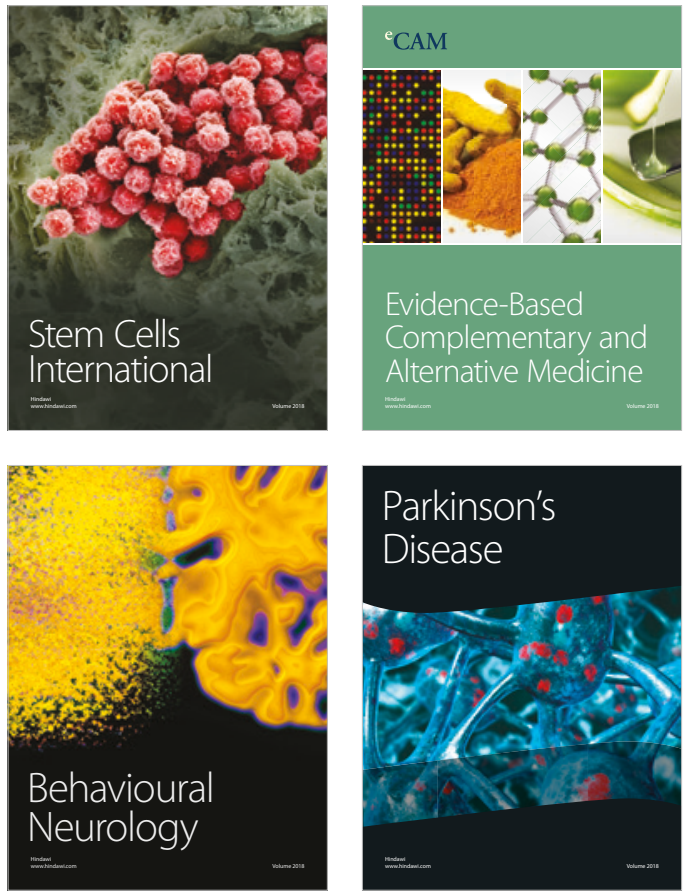

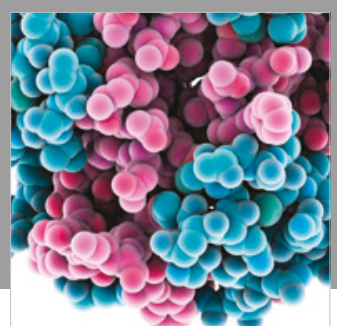

ournal of

Diabetes Research

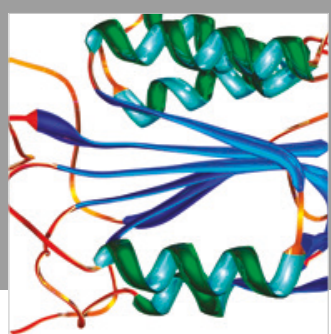

Disease Markers
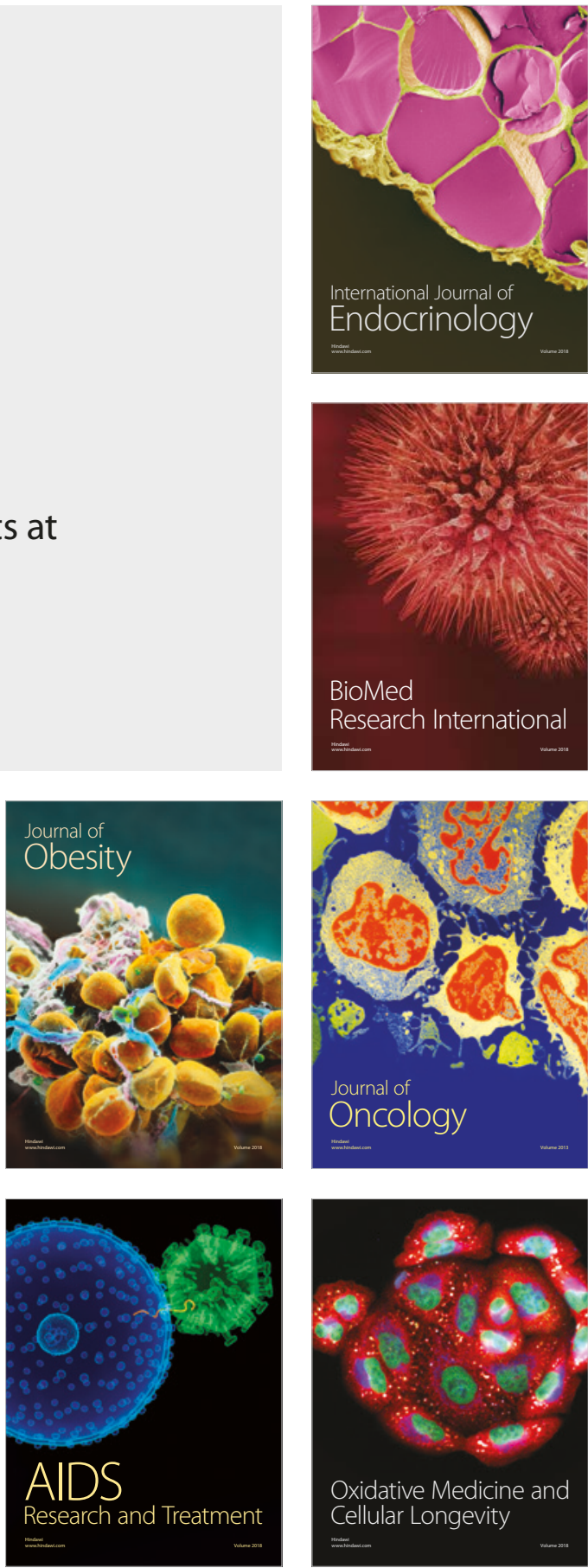